\title{
Evaluation of Infrastructure in Ibadan Metropolis, Nigeria
}

\author{
Solomon Olatunji ${ }^{1}$ \\ Adewale Yoade ${ }^{*}$ \\ Sesan Adeyemi ${ }^{2}$
}

\begin{abstract}
The study examined the quantity and quality of infrastructure in Ibadan, Nigeria with a view to using the information to provide policy guidelines for sustainable infrastructural development. Using stratified sampling technique, a total of fifteen wards from the five local government areas in Ibadan metropolis were selected for study. The selection of all the local government areas is based on the fact that all of them cut across all the residential zones in the metropolis and they all topologically converge at the center of the city. Primary data for the study were sourced through the questionnaire administered on 1,035 respondents (2\% of household heads in all the residential buildings in the metropolis), using systematic sampling technique. Descriptive and inferential statistics were employed to analyze the data earned. Findings established that 93.14\%, 92.27\%, 75.07\%, 68.99\% and $68.02 \%$ of the residents had access to nursery/primary school, market, secondary school and mosque respectively. Moreover, while maternity center was accessed by $66.57 \%$, communication facility was used by $58.16 \%$. Although, library was available and accessed by residents, its usage was the least $(5.22 \%)$ in the study area. The five facilities that residents were very dissatisfied with were waste disposal facilities, nursery/primary school, security/police post, recreational facilities and transport network. The study revealed that facilities such as water supply, restaurant, dispensary, drainage, electricity supply, waste disposal, and fire station, were insufficiently available in the study area. Thus, the study concluded that infrastructure facilities in Ibadan metropolis were poor.
\end{abstract}

Keywords: Infrastructure, facilities, quality of life, management, environment

\footnotetext{
${ }^{1}$ Wesley University Ondo, Department of Urban and Regional Planning, ${ }^{*}$ Corresponding author email: yoadewale@ yahoo.com ${ }^{2}$ University of Lagos Department of Urban and Regional Planning
}

Ghana Journal of Geography Vol. 13 (1), 2021 pages 81-102

https://dx.doi.org/10.4314/gjg.v13i1.5 


\section{Introduction}

The term "infrastructure" can be used to cover all "physical facilities, institutions and organization structures, or the social and economic foundations, for the operation of a society" (United Nations, 2008; Udoka, 2013), and social infrastructure (for example health and education) is usually characterized from economic infrastructure. Infrastructure usually refers to the systems and fundamental facilities needed to assist an area, city or country (UNDP, 2004). Such facilities are typically roads, water supply, electricity, sewers, etc. that enable, sustain or promote the standard of living of people; infrastructure is the enterprise or the products, services and facilities essential for the economy to function appropriately. Providing infrastructural amenities for housing means putting the first basic amenities and services needed by every household in place for numerous schemes and pursuits. However, providing such amenities is one of the numerous complex challenges cities face in developing countries such as Nigeria as they are not able to provide these infrastructures for the filled urban population (Oyesiku, 2010; World Bank, 2012; Gatauwa \& Murungi, 2015).

Infrastructural development in many nations is one of the mandatory medium of assessing the achievements of the government and for establishing an excellent control management (Kolawole, 2014). It confirms that whenever people are declined of basic infrastructure, the result is deprivation leading to urban communities with the substantial total of impoverished individuals. Housing provision and housing infrastructure are entwined. Without infrastructure, housing cannot be viable and hence the former should be treated as part to the latter. A model urban community should be supplied with suitable roads, drainage networks, electricity and potable water supply, good waste management system and security (Bovaird \& Loffler, 2003; Lucas et al., 2003).

The state of these services in Nigerian urban community contradicts the principle of sustainability in urban housing. A sustainable housing development would not only have environment agreeable and energy efficient buildings, it would also have access to employment, schools, shops, places of entertainment, and primary health care, and it would be accessible by public transport (Kolawole, 2014). Subsequently, the provision of sufficient infrastructural amenities is an important segmentt of housing provision especially in developing countries like Nigeria. There is thus a need for research into the condition of infrastructural supply in mass and public housing developments to reveal the present condition of infrastructural decline, and its causalities and identify ways to attain the right standard of living for people. One important segment of the urban housing challenge is the poor state of 
the provided infrastructure (Mabogunje, 1968; Ajanlekoko, 2001; Noll, 2004; Omar, 2009; Veenhoven, 2017).

Findings on housing supply tend to focus on problems of policy, funding, and financial conditions of housing procurement problems, with, infrastructure being dealt with en-passant. However, as interest in quality housing has multiplied, researchers are looking for approaches to present housing from a holistic point of view. The function of infrastructure in housing provision cannot be overstated, nor should it to dealt with as a very little thought (Sirgy \& Cornwell, 2002; United State Environmental Protection Agency (USEPA), 2006).

However, the infrastructural base of any country constitutes the backbone of its socio-economic development. Alabi (2010) stated that infrastructural development has in recent time assumed a central importance in Nigeria's effort to attain social and economic stability. Infrastructure is generally referred to as the physical and organizational structures necessary for the functioning of society (Olujimi \& Bello, 2009; Orekan, 2015). The United Nations Population Fund (UNPF) (2007) reported that Nigeria's infrastructures are grossly inferior in terms of quality and quantity to those existing in other parts of the world. This was corroborated by Alabi (2010) who observed that infrastructure in Nigeria is in a state of negligence and disrepair.

The infrastructure listed as lacking in Nigeria form the WHO survey 2007 includes insufficient or lack of provision of pipe borne or potable drinking water, poor road network, poor waste management and inefficient electricity supply. Das (2008) reported that these infrastructures are grossly inadequate, inequitably spread, where available and in a state of decay, which point to the inability of the provided infrastructure to meet the needs of the teaming population, itself a result of the influx of people into the cities due to migration and a high birth rate. These phenomenal growths exert a tremendous pressure on the existing infrastructure (Ajibola, Awodiran \& Salu-Kosoko, 2013; Asikhia \& Uyoyoghene, 2011; United Nations Economic Commission for Africa (UNECA), 2013).

Frischmann's theory of infrastructure and commons established that, the state is generally responsible for the provision of infrastructure through numerous revenue sources including state resources and tax from citizens and organizations. It has been observed that there is a genuine deficit of infrastructure in Nigeria in terms of both quality and quantity (Pacione, 2003; Ventegogt et al., 2003; Flora, 2004; Oluseyi, 2006; Oyesiku, 2009; Ajanlekoko, 2001). There are quite a number of obstacles facing the development of infrastructure in Nigeria including the issues of finance, technology for development, maintenance design, quality and standards, and sustainability. In recent years, Nigeria has administered many significant infrastructural 
sector reforms, with obstacles persisting in numerous sectors. Further, Omole (2010) has emphasized that in Nigeria housing is a component of the environment that has great impact on the health, efficiency, social behavior, and general life satisfaction of the community. The researchers concluded that cultural, social and economic worth of the community are the best physical and historical affirmation of the civilization of a country. The studies cited above did not consider the facilities that satisfied the respondents more than others. It is against this background that this study examined infrastructure facilities in Ibadan metropolis, Nigeria.

\section{Research methodology}

\section{Study area}

Ibadan is located on a hilly terrain; this makes it a defensive site. It has an elevation of about 210 meters above the sea level. It is located between latitude $7^{\circ} 05 \mathrm{~N}$ and $7^{\circ} 25 \mathrm{~N}$ and longitude $32{ }^{\circ} 40 \mathrm{E}$ and $32^{\circ} 55 \mathrm{E}$ and lies approximately at a distance of 145 kilometers north east of Lagos. As a result of its location within the tropics, the city is identified by a fairly uniform temperature, moderate rainfall, high relative humidity as well as the vegetation situated on the derived savannah vegetation zone. The zone is made up of woodland, secondary forests and tropic vegetation communities as well as mixed cropping and farmland (Ajao et al. 2002). The vegetation type (i.e. derived savannah) is the result of pressure on land use due to high population density and agriculture. The geographical presentation of the study area within the regional context of Nigeria is shown in Figure 1. 


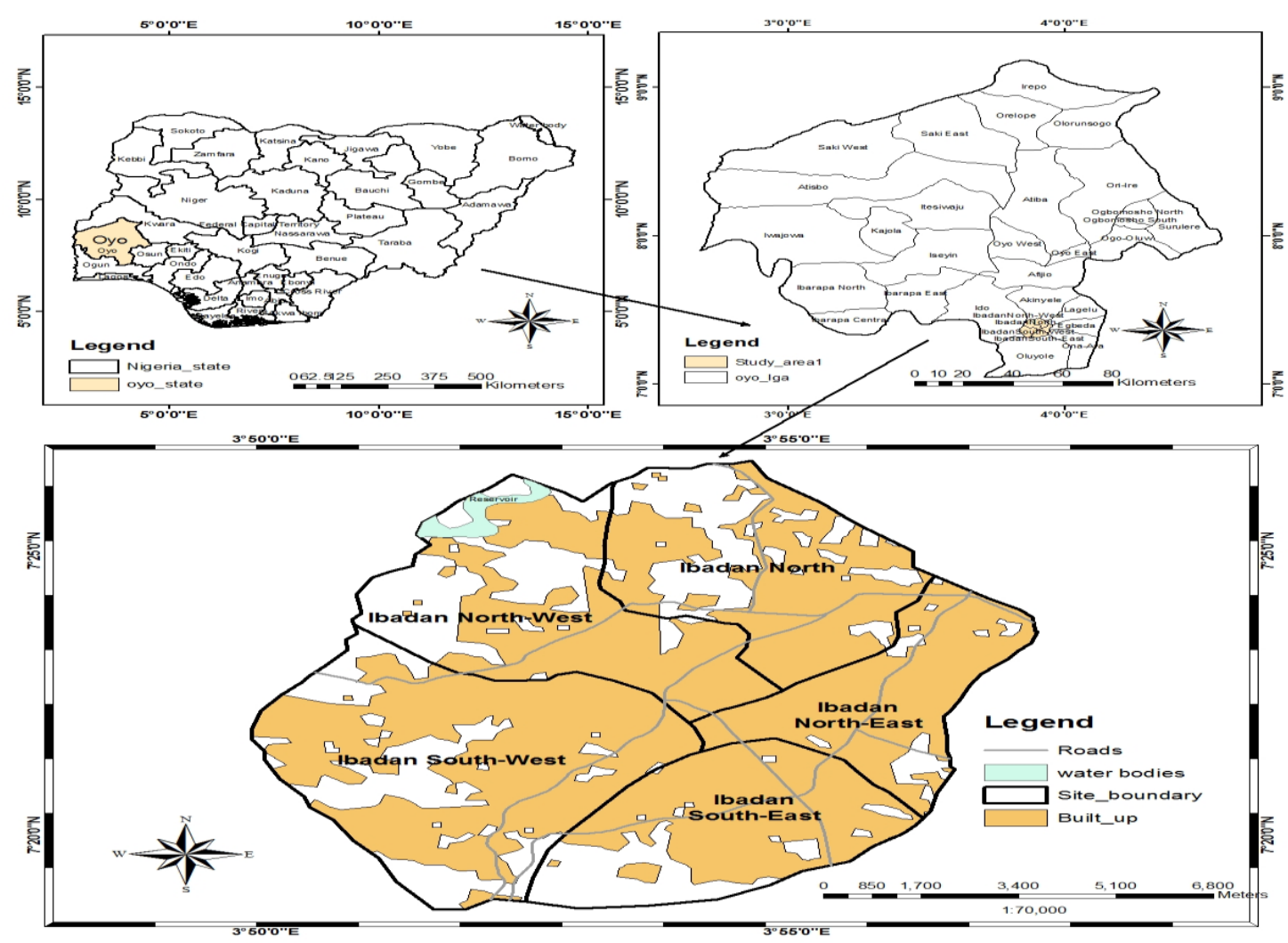

Figure 1. Map of the study area in the Nigerian context

\section{Sampling procedure}

A multi-stage sampling technique was employed for data collection. The first stage is the selection of the five Local Government Areas in the metropolis. These are Ibadan North, Ibadan North East, Ibadan North West, Ibadan South East and Ibadan South West. The selection of all the local government areas is established on the fact that all of them cut across all the residential zones in the metropolis and they all spatially converge at the center of the city. The second stage involves the stratification of study areas into residential zones based on the Afon (2000, 2007) scheme: the core, transition and suburban. Furthermore, local government areas in Ibadan metropolis were stratified into the existing political wards, as recognized by the Oyo State Independent Electoral Commission (2012) in the conduct of electoral polls. According to a pilot study, the total number of political wards in Ibadan metropolis was 59. Ibadan North, Ibadan North East, Ibadan South East and Ibadan South West had twelve (12) political wards each while Ibadan North West comprised eleven (11) political wards. The spatial distribution of political wards showed that there were 29, 17 and 23 wards in the core, transition and suburban zones respectively. 
In the third stage, a ward in each residential zone of Ibadan North, Ibadan North East, Ibadan North West, Ibadan South East and Ibadan South West was selected randomly without replacement for questionnaire administration. Through this method, a total of fifteen (15) wards were selected for survey consisting of One (1) ward each from the core, transition and suburban zones of the five local government area council of Ibadan metropolis. This selection represents $33.8 \%$ of the sampling frame.

The primary and the secondary data which were obtained through the GPS field operations. The quick bird image and existing maps were integrated together in the ArcGIS software from which local queries were performed to produce a GIS database containing the facilities in Ibadan metropolis.

As presented in Table 1, information from the Google Earth and reconnaissance surveys revealed that there were 51, 351 buildings in the selected political wards across the three residential zones of the metropolis. These comprised 26, 427 buildings in the core residential zone, 14,924 buildings in the transition zone and 10,417 buildings in the suburban zone. A systematic sampling technique was employed to identify where households heads would be selected for survey. The first building was chosen randomly. Subsequent units of investigation consisted of every $50^{\text {th }}$ building in each ward, representing $2 \%$ of the buildings in the selected wards. Thus, 1,035 buildings were sampled, comprising 528 buildings in the core residential zone, 299 in the transition zone and 208 in the sub-urban zone. A household head was the respondent selected from a sampled building. In cases where the household head was not available, any available adult was sampled. Thus, a total of 1,035 copies of questionnaire were administered for the study. 
Evaluation of Infrastructure in Ibadan Metropolis, Nigeria

Table 1: Buildings in the different residential zones where household heads were selected for survey

\begin{tabular}{|c|c|c|c|c|c|c|c|}
\hline \multirow{2}{*}{\multicolumn{2}{|c|}{ Residential Areas }} & \multirow{2}{*}{$\begin{array}{l}\text { Ibadan } \\
\text { North }\end{array}$} & \multirow{2}{*}{$\begin{array}{l}\text { Ibadan } \\
\mathrm{NE}\end{array}$} & \multirow{2}{*}{$\begin{array}{l}\text { Ibadan } \\
\text { NW }\end{array}$} & \multirow{2}{*}{$\begin{array}{l}\text { Ibadan } \\
\text { SE }\end{array}$} & \multirow{2}{*}{$\begin{array}{l}\text { Ibadan } \\
\text { SW }\end{array}$} & \multirow{2}{*}{ Total } \\
\hline & & & & & & & \\
\hline \multirow[t]{2}{*}{ Core } & $\begin{array}{l}\text { Total } \\
\text { Buildings }\end{array}$ & 3556 & 6224 & 4805 & 5433 & 6409 & 26427 \\
\hline & Sampled Buildings & 71 & 124 & 96 & 109 & 128 & 528 \\
\hline \multirow{2}{*}{ Transition } & $\begin{array}{l}\text { Total } \\
\text { Buildings }\end{array}$ & 5673 & 2580 & 1857 & 2238 & 2576 & 14924 \\
\hline & Sampled Buildings & 113 & 52 & 37 & 45 & 52 & 299 \\
\hline \multirow[t]{2}{*}{ Sub-urban } & $\begin{array}{l}\text { Total } \\
\text { Buildings }\end{array}$ & 2315 & 2195 & 2122 & 1792 & 1993 & 10417 \\
\hline & Sampled Buildings & 46 & 44 & 42 & 36 & 40 & 208 \\
\hline \multirow[t]{2}{*}{ Total } & $\begin{array}{l}\text { Total } \\
\text { Buildings }\end{array}$ & 11544 & 10999 & 8784 & 9463 & 10561 & 51351 \\
\hline & Sampled Buildings & 232 & 220 & 176 & 192 & 212 & 1035 \\
\hline
\end{tabular}

Source: Author's Field Survey, 2018

Also, residents were made to express their opinion on the condition of the facilities in their locality using a five-point Likert scale of 'Very Good' (VG), Good' (G), 'Neither Poor nor Good' (NPNG), 'Poor' (P) and 'Very Poor'(VP). Therefore, respondents also rated their level of satisfaction on each facility using a five-point Likert scale of 'Very Dissatisfied, 'Dissatisfied', 'Just Satisfied, 'Satisfied and 'Very Satisfied'. The level of satisfaction was measured by an index called Residents' Satisfaction in Infrastructure Index (RSII). 


\section{Findings and Discussion}

Infrastructure is said to be the systematic framework, which underpins a community's ability to fulfil its mission of providing a base for its citizens to be productive and of nurturing social equity (Eastman \& Hong, 2000). It is also seen as a wide range of economic and social facilities key to creating an enabling environment for economic growth and enhancing quality of life (Veenhoven, 2002, 2017; Costanza, 2008). To this end, it is imperative to see whether infrastructural facilities are available and adequate as well as to observe how their quality meets the residents' needs. It is also significant to aware the magnitude to which the facilities are satisfactory and contribute to the residents' quality of life.

\section{Distribution of available infrastructural facilities}

The spatial distribution of infrastructural facilities in Ibadan metropolis has been mapped through GIS by this study. Table 2 shows the number of facilities within the localities with the highest number of facilities in Ibadan metropolis while Fig 1 is a graphic representation of the result. It can be observed that more facilities are found around Iwo Road and Bashorun area which feature $12.15 \%$ of the total number of facilities mapped. This is followed by Eleyele with $8.05 \%$. Other areas where there are higher numbers of facilities include Onipasan, Old Ife Road, Oke-Adu, Okeofa, Onipasan, GRA Agodi and New Bodija. 
Table 2. Localities with the highest number of facilities in Ibadan metropolis

\begin{tabular}{|c|c|c|}
\hline Localities & Number of Facilities & $\%$ of Total \\
\hline Iwo road, Bashorun & 86 & 12.15 \\
\hline Eleyele & 57 & 8.05 \\
\hline Onipasan, Old Ife Road, Oke-Adu, Okeofa, Onipasan & 50 & 7.06 \\
\hline GRA Agodi, Bashorun, Ikolaba, Ashi, New Bodija, Inu-Koko & 42 & 5.93 \\
\hline Ring Road, Abeokuta road, Oke Ayo, Odoona & 35 & 4.94 \\
\hline Odoye, Yemetu, Oritamefa, Agbadagbudu, Oje & 30 & 4.24 \\
\hline Challenge, Passport Office, Oluyole Estate, Ring road & 28 & 3.95 \\
\hline Agugu, Agugu-Oremeji, Koloko, Oluyoro-Okeofa & 27 & 3.81 \\
\hline Iyaganku, Dugbe, Cocoa House, Oke-Bola & 20 & 2.82 \\
\hline Poly, Sango, Samonda, UI & 19 & 2.68 \\
\hline UCH, Ola Bodija, Mokola & 19 & 2.68 \\
\hline Adekile, Gbelekale, Aperin, Ojagbo, Aremo, Koloko & 18 & 2.54 \\
\hline Ibuko, Adelabu, Felele layout, Onibonje, Olorunsogo & 17 & 2.4 \\
\hline Oke-Ado, Cuso, Adeoyo Hospital & 17 & 2.4 \\
\hline Agbowo, Bodija Market, Aponrin & 15 & 2.12 \\
\hline Ring Road, Anfani, Challenge, Molete & 15 & 2.12 \\
\hline Agodi, Kube, Oke-Apon,Itubaba-Ita-Akinloye & 12 & 1.69 \\
\hline Aremo, Alalubosa, Babasale, Ile-Eja, Ode-Aje, Okeofa-Atipe & 12 & 1.69 \\
\hline Beere, Kannike, Oke-Are, Odo-Oye, Isale-Alfa & 12 & 1.69 \\
\hline Ojagbo, Alafara-Olubadan, Aremo, Atipe, Idi Radio, Ojagbo & 11 & 1.55 \\
\hline Oketedo & 11 & 1.55 \\
\hline Oyapidan, Olomi, Eleta, Odinjo, Ile tuntun & 11 & 1.55 \\
\hline Sango, Ijokodo, OkeItunnu, Alaro, Okoro & 11 & 1.55 \\
\hline Sabo & 10 & 1.41 \\
\hline Agbeni, Amunigun, Idikan, Ogunpa, Ayeye, Lanigun & 8 & 1.13 \\
\hline Babasale, Oke Market, Irefin, Oke & 8 & 1.13 \\
\hline Inalende, Oniyanrin, Oke-Iloro, Bola & 8 & 1.13 \\
\hline
\end{tabular}

Source: Author's Fieldwork, 2018

The GIS spatial queries carried out in this work enabled the residents to be provided with a list of social, economic and environmental infrastructure in their locality to indicate whether the facilities were accessible to them. 
Through the summary of the map below, it was revealed that facilities were in varying degree of availability in Ibadan metropolis as shown in Figure 2.

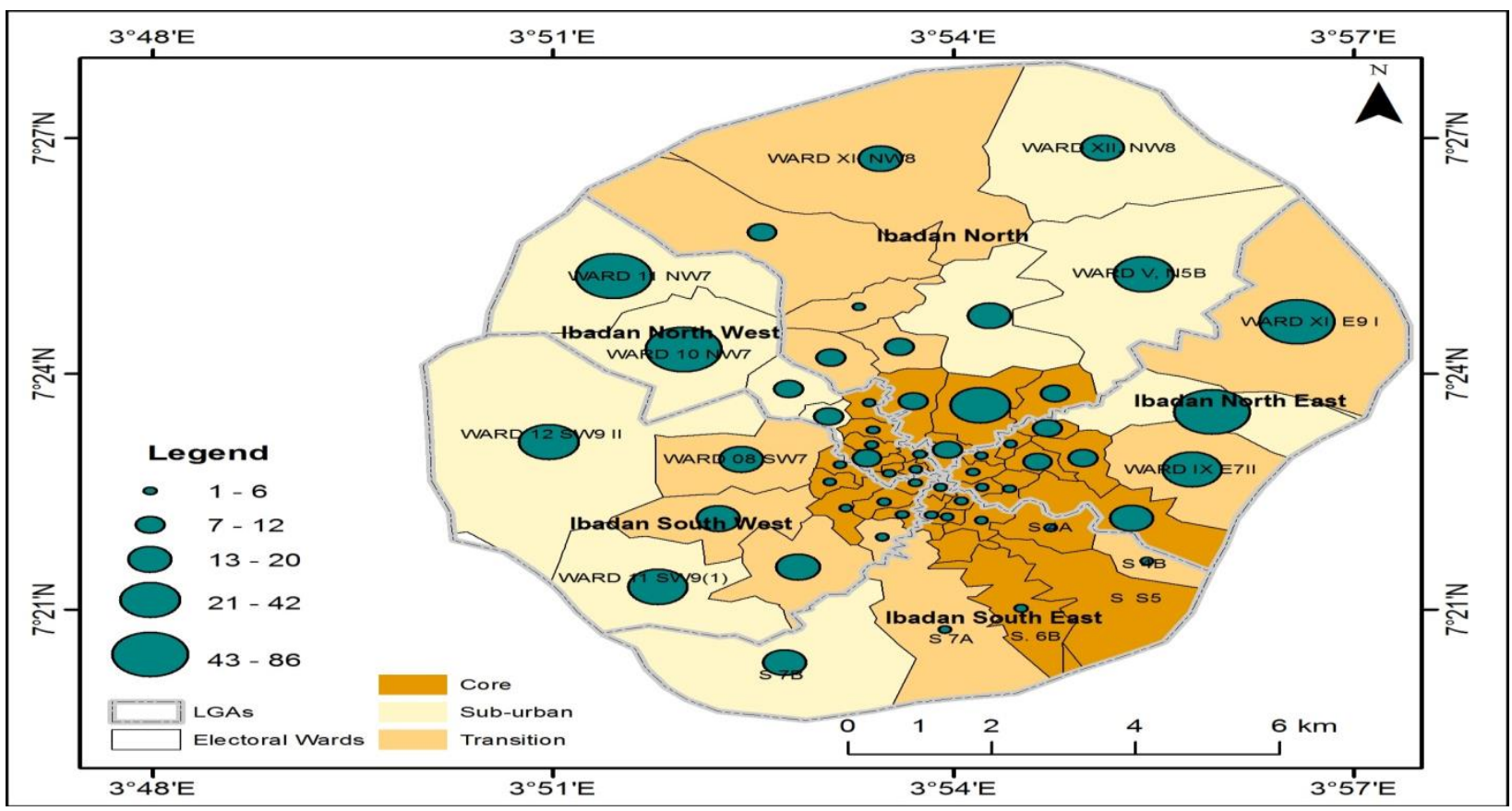

Figure 2. Availability of infrastructure in the residential areas of Ibadan Metropolis

In terms of access, to the facilities in Ibadan metropolis, it is revealed in Table 3 that $93.14 \%$, $92.27 \%, 75.07 \%, 68.99 \%$ and $68.02 \%$ of the residents had access to nursery/primary school, market, secondary school, mosque and church in that order. Moreover, while maternity center was accessed by $66.57 \%$, communication facility was used by $58.16 \%$. Although, library was available and accessed by residents, was the least used (5.22\%) in the study area. 
Evaluation of Infrastructure in Ibadan Metropolis, Nigeria

Table 3. Access to Facilities

\begin{tabular}{|c|c|c|c|c|c|c|c|c|}
\hline \multirow[b]{2}{*}{ Infrastructure } & \multicolumn{4}{|c|}{ Frequency } & \multicolumn{4}{|c|}{ Percentage (Row) } \\
\hline & Core & Transition & $\begin{array}{l}\text { Sub- } \\
\text { urban }\end{array}$ & $\begin{array}{l}\text { Ibadan } \\
\text { Metropolis }\end{array}$ & Core & Transition & $\begin{array}{l}\text { Sub- } \\
\text { urban }\end{array}$ & $\begin{array}{l}\text { Ibadan } \\
\text { Metropolis }\end{array}$ \\
\hline Nursery/Primary School & 506 & 270 & 188 & 964 & 52.49 & 28.01 & 19.50 & 100.00 \\
\hline Market & 488 & 275 & 192 & 955 & 51.10 & 28.80 & 20.10 & 100.00 \\
\hline Secondary School & 379 & 236 & 162 & 777 & 48.78 & 30.37 & 20.85 & 100.00 \\
\hline Mosque & 361 & 208 & 145 & 714 & 50.56 & 29.13 & 20.31 & 100.00 \\
\hline Church & 332 & 218 & 154 & 704 & 47.16 & 30.97 & 21.88 & 100.00 \\
\hline Maternity Center & 350 & 196 & 143 & 689 & 50.80 & 28.45 & 20.75 & 100.00 \\
\hline Communication facilities & 290 & 186 & 126 & 602 & 48.17 & 30.90 & 20.93 & 100.00 \\
\hline Transportation network & 270 & 177 & 131 & 578 & 46.71 & 30.62 & 22.66 & 100.00 \\
\hline Organized open space & 285 & 130 & 103 & 518 & 55.02 & 25.10 & 19.88 & 100.00 \\
\hline Water supply & 237 & 159 & 118 & 514 & 46.11 & 30.93 & 22.96 & 100.00 \\
\hline Restaurant & 220 & 131 & 153 & 504 & 43.65 & 25.99 & 30.36 & 100.00 \\
\hline Dispensary & 322 & 76 & 76 & 474 & 67.93 & 16.03 & 16.03 & 100.00 \\
\hline Drainage facilities & 184 & 135 & 117 & 436 & 42.20 & 30.96 & 26.83 & 100.00 \\
\hline Electricity Supply & 194 & 138 & 94 & 426 & 45.54 & 32.39 & 22.07 & 100.00 \\
\hline Waste Disposal Facilities & 157 & 149 & 114 & 420 & 37.38 & 35.48 & 27.14 & 100.00 \\
\hline Fire Station & 175 & 132 & 67 & 374 & 46.79 & 35.29 & 17.91 & 100.00 \\
\hline Public toilet & 158 & 119 & 92 & 369 & 42.82 & 32.25 & 24.93 & 100.00 \\
\hline General Hospital & 117 & 105 & 89 & 311 & 37.62 & 33.76 & 28.62 & 100.00 \\
\hline Recreational facilities & 99 & 97 & 81 & 277 & 35.74 & 35.02 & 29.24 & 100.00 \\
\hline Post office/postal service & 125 & 72 & 54 & 251 & 49.80 & 28.69 & 21.51 & 100.00 \\
\hline Convenience stores & 110 & 73 & 63 & 246 & 44.72 & 29.67 & 25.61 & 100.00 \\
\hline Good layout plan & 6 & 19 & 30 & 55 & 10.91 & 34.55 & 54.55 & 100.00 \\
\hline Library & 0 & 54 & 0 & 54 & 0.00 & 100.00 & 0.00 & 100.00 \\
\hline Community Centre & 50 & 55 & 36 & 141 & 35.46 & 39.01 & 25.53 & 100.00 \\
\hline
\end{tabular}

Source: Field Survey, 2018 
Ghana Journal of Geography Vol. 13 (1), 2021 pages 81-102

Variation across the three residential areas revealed that nursery/primary school was relatively higher $(95.83 \%)$ in core residential areas, as against $90.30 \%$ and $90.38 \%$ respectively in transition and sub-urban residential areas. Similarly, it was observed that accessibility to library was not adequate/enough except in transition residential area where a proportion $(18.06 \%)$ of the residents indicated that the facility was available.

Presented in Table 4 is the aggregate residents' view on how adequate each of the identified facilities was in the study area. The nearer the FAI to 5, the more adequate the facilities were considered by residents. The average facility adequacy ( $\left.F A I_{\text {Ibadanmetropolis }}\right)$ for the study area was 2.64. This implied that facilities in the study area were not adequate as perceived by respondents as the index of 2.64 lay close to 'adequate'.

Table 4. Facility Adequacy Index of the Identified Facilities in Ibadan Metropolis

\begin{tabular}{lllllll}
\hline \multirow{2}{*}{ Infrastructure } & \multicolumn{3}{l}{ Frequency } & \multicolumn{4}{c}{ Percentage (Column) } \\
\cline { 2 - 7 } & Core & Transition & $\begin{array}{l}\text { Sub- } \\
\text { urban }\end{array}$ & Core & Transition & $\begin{array}{l}\text { Sub- } \\
\text { urban }\end{array}$ \\
\hline Nursery/Primary School & 506 & 270 & 188 & 9.34 & 7.92 & 7.44 \\
Market & 488 & 275 & 192 & 9.01 & 8.06 & 7.59 \\
Secondary School & 379 & 236 & 162 & 7.00 & 6.92 & 6.41 \\
Mosque & 361 & 208 & 145 & 6.67 & 3.84 & 5.74 \\
Church & 332 & 218 & 154 & 6.13 & 4.03 & 6.09 \\
Maternity Center & 350 & 196 & 143 & 6.46 & 3.62 & 5.66 \\
Communication facilities & 290 & 186 & 126 & 5.36 & 3.43 & 4.98 \\
Transportation network & 270 & 177 & 131 & 4.99 & 3.27 & 5.18 \\
Organized open space & 285 & 130 & 103 & 5.26 & 2.40 & 4.07 \\
Water supply & 237 & 159 & 118 & 4.38 & 2.94 & 4.67 \\
Restaurant & 220 & 131 & 153 & 4.06 & 2.42 & 6.05 \\
Dispensary & 322 & 76 & 76 & 5.95 & 1.40 & 3.01 \\
Drainage facilities & 184 & 135 & 117 & 3.40 & 2.49 & 4.63 \\
Electricity Supply & 194 & 138 & 94 & 3.58 & 2.55 & 3.72 \\
Waste Disposal Facilities & 157 & 149 & 114 & 2.90 & 2.75 & 4.51 \\
Fire Station & 175 & 132 & 67 & 3.23 & 2.44 & 2.65 \\
Public toilet & 158 & 119 & 92 & 2.92 & 2.20 & 3.64 \\
General Hospital & 117 & 105 & 89 & 2.16 & 1.94 & 3.52 \\
Recreational facilities & 99 & 97 & 81 & 1.83 & 1.79 & 3.20 \\
Post office/postal service & 125 & 72 & 54 & 2.31 & 1.33 & 2.14 \\
Convenience stores & 110 & 73 & 63 & 2.03 & 1.35 & 2.49 \\
Good layout plan & 6 & 19 & 30 & 0.11 & 0.35 & 1.19 \\
Library & 0 & 54 & 0 & 0.00 & 1.00 & 0.00 \\
Community Centre & 50 & 55 & 36 & 0.92 & 1.02 & 1.42 \\
Total & 5415 & 3410 & 2528 & 100.00 & 71.45 & 100.00 \\
\hline & & & & & & \\
\hline
\end{tabular}

Source: Field Survey, 2018

However, the level of satisfaction derived from these facilities in the study area was 3.18 as presented in Table 5. An index close to 3 ( is, 'just satisfied' ). The five most adequate facilities to residents and their corresponding satisfaction derived were church $(\mathrm{FAI}=4.44$; $\mathrm{RSII}=4.16)$, mosque $(\mathrm{FAI}=4.44 ; \mathrm{RSII}=2.41)$, nursery/primary school $(\mathrm{FAI}=4.18 ; \mathrm{RSII}=2.65)$, secondary 
school (FAI=3.96; RSII=3.15) and market (FAI=3.45; RSII=3.19). On the other hand, facilities such as waste disposal (FAI=1.41; RSII=2.83), recreation (FAI=1.59; RSII=2.84), parking/open space $(\mathrm{FAI}=1.62 ; \mathrm{RSII}=3.31)$ and drainage $(\mathrm{FAI}=1.63 ; \mathrm{RSII}=3.99)$ were perceived as most inadequate in the study area. Waste disposal facility with an index of 1.41 was perceived to be the least adequate in the study area. This finding supports the claim of Taiwo (2014) who submitted that waste generated by beggars (who were also residents) was indiscriminately disposed wherever they were found. This was due to inadequacy of waste disposal facilities.

Table 5. Residents' Perceived Satisfaction on Facilities in Ibadan Metropolis

\begin{tabular}{|c|c|c|c|c|c|c|c|c|}
\hline Facilities & VD & $\mathrm{D}$ & JS & 4 & $\begin{array}{l}\text { VS } \\
5 \\
\end{array}$ & SWV & RSII & $\begin{array}{l}\text { Deviation } \\
\text { about } \\
\text { the Mean }\end{array}$ \\
\hline Church & 9 & 20 & 231 & 2580 & 1470 & 4310 & 4.16 & 0.98 \\
\hline $\begin{array}{l}\text { Drainage } \\
\text { facilities }\end{array}$ & 4 & 4 & 48 & 3948 & 130 & 4134 & 3.99 & 0.81 \\
\hline Dispensary & 10 & 58 & 75 & 3764 & 150 & 4057 & 3.92 & 0.74 \\
\hline Electricity supply & 27 & 90 & 282 & 3436 & 50 & 3885 & 3.75 & 0.57 \\
\hline Fire station & 0 & 8 & 909 & 2912 & 0 & 3829 & 3.7 & 0.52 \\
\hline Public toilet & 2 & 248 & 543 & 2912 & 0 & 3705 & 3.58 & 0.4 \\
\hline Open space & 0 & 0 & 2157 & 1264 & 0 & 3421 & 3.31 & 0.13 \\
\hline Market & 0 & 4 & 1833 & 1464 & 0 & 3301 & 3.19 & 0.01 \\
\hline Secondary School & 2 & 0 & 2562 & 700 & 0 & 3264 & 3.15 & -0.03 \\
\hline $\begin{array}{l}\text { Security/Police } \\
\text { Post }\end{array}$ & 0 & 240 & 1995 & 784 & 0 & 3019 & 2.92 & -0.26 \\
\hline $\begin{array}{l}\text { Waste Disposal } \\
\text { Facilities }\end{array}$ & 0 & 362 & 2562 & 0 & 0 & 2924 & 2.83 & -0.35 \\
\hline $\begin{array}{l}\text { Nursery/Primary } \\
\text { school }\end{array}$ & 0 & 734 & 2004 & 0 & 0 & 2738 & 2.65 & -0.53 \\
\hline $\begin{array}{l}\text { Transport } \\
\text { network }\end{array}$ & 2 & 840 & 1635 & 40 & 30 & 2547 & 2.46 & -0.72 \\
\hline $\begin{array}{l}\text { Recreational } \\
\text { facilities }\end{array}$ & 0 & 4 & 2931 & 0 & 0 & 2935 & 2.84 & -0.72 \\
\hline Mosque & 2 & 1300 & 1047 & 112 & 30 & 2491 & 2.41 & -0.77 \\
\hline Water supply & 25 & 1802 & 273 & 72 & 0 & 2172 & 2.1 & -1.08 \\
\hline
\end{tabular}

$$
\overline{R S I I}_{\text {Ibadan metropolis }}=\frac{\sum R S I I}{(N=16)}=\frac{50.96}{16}=3.18 \quad \text { Source: Field Survey, } 2018
$$

\section{Adequacy of and satisfaction with facilities in the core residential area}

Presented in Tables 6 and 7 were residents' view on how adequate each of the identified facilities was in the core residential area as well as the satisfaction they derived from them. The average FAI for the core $\left(F A I_{\text {core }}\right)$ was 2.62 , and the $R S I I_{\text {Core }}$ was 3.17 . These indices were close to 'adequate' and 'just satisfied'. Facilities that were of significance to this study were those 
Ghana Journal of Geography Vol. 13 (1), 2021 pages 81-102

with indices greater than the average (that is, FAI Ibadan metropolis and RSII Ibadan metropolis) of the study area and those below them. Church and mosque were the facilities considered to be the most adequate with an index of 4.46 each. Their equivalent satisfaction indices were 4.14 and 2.38 respectively.

Table 6. Facility Adequacy Index of the Identified Facilities in Core

\begin{tabular}{|c|c|c|c|c|c|c|c|c|}
\hline \multirow{2}{*}{ Facilities } & NAA & NA & A & VA & VMA & \multirow{2}{*}{ SWV } & \multirow{2}{*}{ FAI } & \multirow{2}{*}{$\begin{array}{l}\text { Deviation } \\
\text { about } \\
\text { the Mean }\end{array}$} \\
\hline & 1 & 2 & 3 & 4 & 5 & & & \\
\hline Church & 0 & 0 & 0 & 1136 & 1220 & 2356 & 4.46 & 1.84 \\
\hline Mosque & 0 & 0 & 0 & 1136 & 1220 & 2356 & 4.46 & 1.84 \\
\hline $\begin{array}{l}\text { Nursery/Primary } \\
\text { school }\end{array}$ & 0 & 0 & 111 & 1368 & 745 & 2224 & 4.21 & 1.59 \\
\hline $\begin{array}{l}\text { Secondary } \\
\text { School }\end{array}$ & 0 & 0 & 0 & 2112 & 0 & 2112 & 4 & 1.38 \\
\hline Market & 0 & 0 & 900 & 912 & 0 & 1812 & 3.43 & 0.81 \\
\hline Dispensary & 69 & 288 & 222 & 944 & 25 & 1548 & 2.93 & 0.31 \\
\hline $\begin{array}{l}\text { Communication } \\
\text { facilities }\end{array}$ & 162 & 62 & 111 & 1168 & 30 & 1533 & 2.9 & 0.28 \\
\hline $\begin{array}{l}\text { Maternity } \\
\text { Center }\end{array}$ & 44 & 378 & 225 & 868 & 15 & 1530 & 2.89 & 0.27 \\
\hline Fire station & 0 & 568 & 618 & 152 & 0 & 1338 & 2.53 & -0.09 \\
\hline $\begin{array}{l}\text { Security/Police } \\
\text { Post }\end{array}$ & 85 & 832 & 15 & 0 & 110 & 1042 & 1.97 & -0.65 \\
\hline Public toilet & 245 & 418 & 162 & 36 & 55 & 916 & 1.73 & -0.89 \\
\hline Library & 276 & 454 & 24 & 40 & 35 & 829 & 1.57 & -1.05 \\
\hline $\begin{array}{l}\text { Parking/open } \\
\text { space }\end{array}$ & 279 & 434 & 60 & 28 & 25 & 826 & 1.56 & -1.06 \\
\hline $\begin{array}{l}\text { Recreational } \\
\text { facilities }\end{array}$ & 309 & 378 & 21 & 64 & 35 & 807 & 1.52 & -1.1 \\
\hline $\begin{array}{l}\text { Drainage } \\
\text { facilities }\end{array}$ & 288 & 446 & 24 & 24 & 15 & 797 & 1.5 & -1.12 \\
\hline $\begin{array}{l}\text { Good layout } \\
\text { plan }\end{array}$ & 307 & 414 & 24 & 8 & 20 & 773 & 1.46 & -1.16 \\
\hline $\begin{array}{l}\text { Waste Disposal } \\
\text { Facilities }\end{array}$ & 365 & 298 & 0 & 44 & 15 & 722 & 1.36 & -1.26 \\
\hline
\end{tabular}

$$
\tau_{\text {FAI }_{\text {core }}}=\frac{\sum F A I}{(N=17)}=\frac{44.48}{17}=2.62
$$

Source: Field Survey, 2018

The least facility in terms of adequacy with an index of 1.36 was waste disposal. The satisfaction index derived in this facility was 2.83 . The facility was close to 'not at all adequate' and 'just satisfied' as perceived by residents. Other facilities that were adequate (above the study area average index) with regards to the satisfaction derived from them included nursery/primary school $(\mathrm{FAI}=4.21$; RSII=2.64), secondary school (FAI=4.00; RSII=3.17), market $(\mathrm{FAI}=3.43 ; \mathrm{RSII}=3.16)$ and dispensary $(\mathrm{FAI}=2.93 ; \mathrm{RSII}=3.91)$. 
Evaluation of Infrastructure in Ibadan Metropolis, Nigeria

Table 7. Residents' Perceived Satisfaction on Facilities in the Core

\begin{tabular}{|c|c|c|c|c|c|c|c|c|}
\hline \multirow{2}{*}{ Facilities } & VD & $\mathrm{D}$ & JS & $\mathrm{S}$ & VS & \multirow{2}{*}{ SWV } & \multirow{2}{*}{ RSII } & \multirow{2}{*}{$\begin{array}{l}\text { Deviation } \\
\text { about } \\
\text { the Mean }\end{array}$} \\
\hline & 1 & 2 & 3 & 4 & 5 & & & \\
\hline Church & 3 & 16 & 138 & 1312 & 715 & 2184 & 4.14 & 0.97 \\
\hline $\begin{array}{l}\text { Drainage } \\
\text { facilities }\end{array}$ & 0 & 0 & 3 & 2108 & 0 & 2111 & 4 & 0.83 \\
\hline Dispensary & 4 & 38 & 36 & 1908 & 80 & 2066 & 3.91 & 0.74 \\
\hline $\begin{array}{l}\text { Electricity } \\
\text { supply }\end{array}$ & 17 & 28 & 150 & 1780 & 10 & 1985 & 3.76 & 0.59 \\
\hline Fire station & 0 & 0 & 468 & 1488 & 0 & 1956 & 3.7 & 0.53 \\
\hline Public toilet & 0 & 116 & 270 & 1520 & 0 & 1906 & 3.61 & 0.44 \\
\hline Open space & 0 & 0 & 1128 & 608 & 0 & 1736 & 3.29 & 0.12 \\
\hline $\begin{array}{l}\text { Secondary } \\
\text { School }\end{array}$ & 0 & 0 & 1314 & 360 & 0 & 1674 & 3.17 & 0 \\
\hline Market & 0 & 0 & 933 & 736 & 0 & 1669 & 3.16 & -0.01 \\
\hline Water supply & 15 & 926 & 135 & 20 & 0 & 1096 & 2.08 & -0.09 \\
\hline $\begin{array}{l}\text { Security/Police } \\
\text { Post }\end{array}$ & 0 & 124 & 1020 & 372 & 0 & 1516 & 2.87 & -0.3 \\
\hline $\begin{array}{l}\text { Waste Disposal } \\
\text { Facilities }\end{array}$ & 0 & 180 & 1314 & 0 & 0 & 1494 & 2.83 & -0.34 \\
\hline $\begin{array}{l}\text { Recreational } \\
\text { facilities }\end{array}$ & 0 & 0 & 1485 & 0 & 0 & 1485 & 2.81 & -0.36 \\
\hline $\begin{array}{l}\text { Nursery/Primary } \\
\text { school }\end{array}$ & 0 & 380 & 1014 & 0 & 0 & 1394 & 2.64 & -0.53 \\
\hline $\begin{array}{l}\text { Transport } \\
\text { network }\end{array}$ & 1 & 432 & 819 & 16 & 10 & 1278 & 2.42 & -0.75 \\
\hline Mosque & 2 & 678 & 513 & 56 & 10 & 1259 & 2.38 & -0.79 \\
\hline
\end{tabular}

$$
\overline{\text { RSII }}_{\text {Core }}=\frac{\sum R S I I}{(N=16)}=\frac{50.77}{16}=3.17
$$

Source: Field Survey, 2018

\section{Adequacy of and satisfaction with facilities in the transition residential area}

From the summary presented in Tables 8 and 9, it was established that the mean FAI and RSII in the transition residential area were 2.75 and 3.20 respectively. This implied that on average, the level of facilities' adequacy and the satisfactions derived from them were 'adequate' and 'just satisfied' as the indices were close to 3 . Facilities that were very adequate to residents in the transition residential area included market, church, mosque, nursery/primary school, and secondary school. Conversely, those that was low in adequacy included fire station, maternity center, dispensary, communication facilities, security/police post, among others. 
Ghana Journal of Geography Vol. 13 (1), 2021 pages 81-102

Table 8. Facility Adequacy Index of the Identified Facilities in Transition

\begin{tabular}{|c|c|c|c|c|c|c|c|c|}
\hline \multirow[t]{2}{*}{ Facilities } & NAA & NA & $\mathrm{A}$ & VA & VMA & \multirow[t]{2}{*}{ SWV } & \multirow[t]{2}{*}{ FAI } & \multirow{2}{*}{$\begin{array}{l}\text { Deviation } \\
\text { about } \\
\text { the Mean }\end{array}$} \\
\hline & 1 & 2 & 3 & 4 & 5 & & & \\
\hline Market & 0 & 0 & 900 & 612 & 0 & 1512 & 5.05 & 2.3 \\
\hline Church & 0 & 0 & 102 & 440 & 775 & 1317 & 4.4 & 1.65 \\
\hline Mosque & 0 & 12 & 84 & 432 & 785 & 1313 & 4.39 & 1.64 \\
\hline $\begin{array}{l}\text { Nursery/Primary } \\
\text { school }\end{array}$ & 0 & 4 & 171 & 552 & 510 & 1237 & 4.13 & 1.38 \\
\hline $\begin{array}{l}\text { Secondary } \\
\text { School }\end{array}$ & 0 & 8 & 84 & 1060 & 10 & 1162 & 3.88 & 1.13 \\
\hline Fire station & 0 & 216 & 483 & 120 & 0 & 819 & 2.73 & -0.02 \\
\hline $\begin{array}{l}\text { Maternity } \\
\text { Center }\end{array}$ & 23 & 264 & 177 & 312 & 35 & 811 & 2.71 & -0.04 \\
\hline Dispensary & 53 & 188 & 165 & 384 & 5 & 795 & 2.65 & -0.1 \\
\hline $\begin{array}{l}\text { Communication } \\
\text { facilities }\end{array}$ & 116 & 30 & 156 & 444 & 25 & 771 & 2.57 & -0.18 \\
\hline $\begin{array}{l}\text { Security/Police } \\
\text { Post }\end{array}$ & 44 & 424 & 120 & 0 & 15 & 603 & 2.01 & -0.74 \\
\hline Public toilet & 100 & 272 & 123 & 80 & 10 & 585 & 1.95 & -0.8 \\
\hline Library & 120 & 274 & 108 & 20 & 5 & 527 & 1.76 & -0.99 \\
\hline $\begin{array}{l}\text { Parking/open } \\
\text { spac }\end{array}$ & 129 & 252 & 111 & 24 & 5 & 521 & 1.74 & -1.01 \\
\hline $\begin{array}{l}\text { Good layout } \\
\text { plan }\end{array}$ & 133 & 246 & 114 & 0 & 25 & 518 & 1.73 & -1.02 \\
\hline $\begin{array}{l}\text { Drainage } \\
\text { facilities }\end{array}$ & 123 & 276 & 102 & 16 & 0 & 517 & 1.72 & -1.03 \\
\hline $\begin{array}{l}\text { Recreational } \\
\text { facilities }\end{array}$ & 148 & 226 & 75 & 28 & 30 & 507 & 1.69 & -1.06 \\
\hline $\begin{array}{l}\text { Waste Disposal } \\
\text { Facilities }\end{array}$ & 167 & 190 & 96 & 16 & 5 & 474 & 1.58 & -1.17 \\
\hline
\end{tabular}

$$
\tau_{\text {FAI }_{\text {Transition }}}=\frac{\sum F A I}{(N=17)}=\frac{46.69}{17}=2.75 \quad \text { Source: Field Survey, } 2018
$$

Findings further revealed that residents were satisfied with facilities such as drainage (4.00), electricity (3.74), fire station (3.71) and public toilet (3.54). Others included open space (3.32) and market (3.27). The least five facilities that residents were very dissatisfied with were waste disposal facilities, nursery/primary school, security/police post, recreational facilities and transport network. 
Evaluation of Infrastructure in Ibadan Metropolis, Nigeria

Table 9. Residents' Perceived Satisfaction on Quality and Quantity of Facilities in the Transition

\begin{tabular}{|c|c|c|c|c|c|c|c|c|}
\hline \multirow{2}{*}{ Facilities } & VD & $\mathrm{D}$ & JS & $S$ & VS & \multirow{2}{*}{ SWV } & \multirow{2}{*}{ RSII } & \multirow{2}{*}{$\begin{array}{l}\text { Deviation } \\
\text { about } \\
\text { the Mean }\end{array}$} \\
\hline & 1 & 2 & 3 & 4 & & & & \\
\hline $\begin{array}{l}\text { Drainage } \\
\text { facilities }\end{array}$ & 0 & 4 & 27 & 1104 & 60 & 1195 & 4 & 0.8 \\
\hline $\begin{array}{l}\text { Electricity } \\
\text { supply }\end{array}$ & 6 & 42 & 54 & 1016 & 0 & 1118 & 3.74 & 0.54 \\
\hline Fire station & 0 & 4 & 246 & 860 & 0 & 1110 & 3.71 & 0.51 \\
\hline Public toilet & 2 & 76 & 165 & 816 & 0 & 1059 & 3.54 & 0.34 \\
\hline Open space & 0 & 0 & 609 & 384 & 0 & 993 & 3.32 & 0.12 \\
\hline Market & 0 & 4 & 519 & 456 & 0 & 979 & 3.27 & 0.07 \\
\hline Water supply & 8 & 538 & 54 & 16 & 0 & 616 & 2.06 & -1.14 \\
\hline $\begin{array}{l}\text { Secondary } \\
\text { School }\end{array}$ & 2 & 0 & 747 & 192 & 0 & 941 & 3.15 & -0.05 \\
\hline Health facility & 2 & 20 & 30 & 1076 & 40 & 1168 & 3.91 & 0.71 \\
\hline Church & 4 & 4 & 54 & 736 & 455 & 1253 & 4.19 & 0.99 \\
\hline Mosque & 0 & 368 & 315 & 24 & 20 & 727 & 2.43 & -0.77 \\
\hline $\begin{array}{l}\text { Transport } \\
\text { network }\end{array}$ & 1 & 252 & 483 & 8 & 0 & 744 & 2.49 & -0.71 \\
\hline $\begin{array}{l}\text { Recreational } \\
\text { facilities }\end{array}$ & 0 & 4 & 861 & 0 & 0 & 865 & 2.89 & -0.31 \\
\hline $\begin{array}{l}\text { Security/Police } \\
\text { Post }\end{array}$ & 0 & 72 & 573 & 256 & 0 & 901 & 3.01 & -0.19 \\
\hline $\begin{array}{l}\text { Nursery/Primary } \\
\text { school }\end{array}$ & 0 & 204 & 591 & 0 & 0 & 795 & 2.66 & -0.54 \\
\hline $\begin{array}{l}\text { Waste Disposal } \\
\text { Facilities }\end{array}$ & 0 & 100 & 747 & 0 & 0 & 847 & 2.83 & -0.37 \\
\hline
\end{tabular}

$$
\mathrm{RSII}_{\text {Transition }}=\frac{\sum R S I I}{(N=16)}=\frac{51.20}{16}=3.20
$$

Source: Field Survey, 2018

\section{Adequacy of and satisfaction with facilities in the sub-urban residential area}

Findings presented in Tables 10 and 11 are the summary of the adequacy residents placed on infrastructural facilities in the sub-urban residential area and the satisfaction they derived from them. The average FAI for the sub-urban residential area $\left(F A I_{\text {sub-urban }}\right)$ was 2.66 , while that of the RSII for the same area (RSII Sub-urban) was 3.19. These indices were also close to 'adequate' and 'just satisfied' as in the transition residential area. Church and mosque were the facilities considered to be the most adequate with an index of 4.47 each. The least adequate facility in this residential area was waste disposal with an index of 1.29. However, it was the only facility that tended towards 'not at all adequate' as perceived by residents. Facilities such as security/police post (1.84), public toilet (1.83), drainage (1.80), library (1.80), good layout plan (1.67), parking/open space (1.60), and recreation (1.59) were close to 'not available'. 
Ghana Journal of Geography Vol. 13 (1), 2021 pages 81-102

Table 10. Facility Adequacy Index of the Identified Facilities in the Sub-Urban

\begin{tabular}{|c|c|c|c|c|c|c|c|c|}
\hline \multirow{2}{*}{ Facilities } & NAA & NA & $\mathrm{A}$ & VA & VMA & \multirow{2}{*}{ SWV } & \multirow{2}{*}{ FAI } & \multirow{2}{*}{$\begin{array}{l}\text { Deviation } \\
\text { about } \\
\text { the Mean }\end{array}$} \\
\hline & 1 & 2 & 3 & 4 & 5 & & & \\
\hline Church & 0 & 0 & 0 & 436 & 495 & 931 & 4.47 & 1.81 \\
\hline Mosque & 0 & 0 & 0 & 436 & 495 & 931 & 4.47 & 1.81 \\
\hline $\begin{array}{l}\text { Nursery/Primary } \\
\text { school }\end{array}$ & 0 & 0 & 48 & 552 & 270 & 870 & 4.18 & 1.52 \\
\hline $\begin{array}{l}\text { Secondary } \\
\text { School }\end{array}$ & 0 & 0 & 0 & 832 & 0 & 832 & 4 & 1.34 \\
\hline Market & 0 & 0 & 351 & 364 & 0 & 715 & 3.43 & 0.77 \\
\hline $\begin{array}{l}\text { Maternity } \\
\text { Centre }\end{array}$ & 9 & 156 & 69 & 392 & 0 & 626 & 3 & 0.34 \\
\hline Dispensary & 26 & 110 & 114 & 356 & 0 & 606 & 2.91 & 0.25 \\
\hline $\begin{array}{l}\text { Communication } \\
\text { facilities }\end{array}$ & 67 & 34 & 33 & 444 & 10 & 588 & 2.82 & 0.16 \\
\hline Fire station & 0 & 218 & 246 & 68 & 0 & 532 & 2.55 & -0.11 \\
\hline $\begin{array}{l}\text { Security/Police } \\
\text { Post }\end{array}$ & 34 & 344 & 6 & 0 & 0 & 384 & 1.84 & -0.82 \\
\hline Public toilet & 86 & 158 & 105 & 32 & 0 & 381 & 1.83 & -0.83 \\
\hline $\begin{array}{l}\text { Drainage } \\
\text { facilities }\end{array}$ & 87 & 182 & 42 & 64 & 0 & 375 & 1.8 & -0.86 \\
\hline Library & 89 & 178 & 36 & 72 & 0 & 375 & 1.8 & -0.86 \\
\hline $\begin{array}{l}\text { Good layout } \\
\text { plan }\end{array}$ & 111 & 142 & 42 & 24 & 30 & 349 & 1.67 & -0.99 \\
\hline $\begin{array}{l}\text { Parking/open } \\
\text { space }\end{array}$ & 109 & 162 & 36 & 16 & 10 & 333 & 1.6 & -1.06 \\
\hline $\begin{array}{l}\text { Recreational } \\
\text { facilities }\end{array}$ & 118 & 144 & 6 & 64 & 0 & 332 & 1.59 & -1.07 \\
\hline $\begin{array}{l}\text { Waste Disposal } \\
\text { Facilities }\end{array}$ & 147 & 122 & 0 & 0 & 0 & 269 & 1.29 & -1.37 \\
\hline
\end{tabular}

$$
\tau_{\text {FAI }_{\text {sub-urban }}}=\frac{\sum F A I}{(N=17)}=\frac{45.25}{17}=2.66 \quad \text { Source: Field Survey, } 2018
$$

These facilities had indices below the average FAI computed for the sub-urban residential area. Findings further revealed that what residents perceived to be very adequate among the facilities were viewed with very much dissatisfaction. These facilities included mosque, nursery/primary school, and market. 
Evaluation of Infrastructure in Ibadan Metropolis, Nigeria

Table 11. Residents' Perceived Satisfaction on Quality and Quantity of Facilities in the Sub-Urban

\begin{tabular}{|c|c|c|c|c|c|c|c|c|}
\hline \multirow{2}{*}{ Facilities } & VD & $\mathrm{D}$ & JS & $\mathrm{S}$ & VS & \multirow{2}{*}{ SWV } & \multirow{2}{*}{ RSII } & \multirow{2}{*}{$\begin{array}{l}\text { Deviation } \\
\text { about } \\
\text { the Mean }\end{array}$} \\
\hline & 1 & 2 & 3 & 4 & 5 & & & \\
\hline Church & 2 & 0 & 39 & 532 & 300 & 873 & 4.2 & 1.01 \\
\hline $\begin{array}{l}\text { Drainage } \\
\text { facilities }\end{array}$ & 4 & 0 & 18 & 736 & 70 & 828 & 3.98 & 0.79 \\
\hline Dispensary & 4 & 0 & 9 & 780 & 30 & 823 & 3.96 & 0.77 \\
\hline $\begin{array}{l}\text { Electricity } \\
\text { supply }\end{array}$ & 4 & 20 & 78 & 640 & 40 & 782 & 3.76 & 0.57 \\
\hline Fire station & 0 & 4 & 195 & 564 & 0 & 763 & 3.67 & 0.48 \\
\hline Public toilet & 0 & 56 & 108 & 576 & 0 & 740 & 3.56 & 0.37 \\
\hline Open space & 0 & 0 & 420 & 272 & 0 & 692 & 3.33 & 0.14 \\
\hline $\begin{array}{l}\text { Secondary } \\
\text { School }\end{array}$ & 0 & 0 & 501 & 164 & 0 & 665 & 3.2 & 0.01 \\
\hline Market & 0 & 0 & 381 & 272 & 0 & 653 & 3.14 & -0.05 \\
\hline $\begin{array}{l}\text { Security/Police } \\
\text { Post }\end{array}$ & 0 & 44 & 402 & 156 & 0 & 602 & 2.89 & -0.3 \\
\hline $\begin{array}{l}\text { Recreational } \\
\text { facilities }\end{array}$ & 0 & 0 & 585 & 0 & 0 & 585 & 2.81 & -0.38 \\
\hline $\begin{array}{l}\text { Waste Disposal } \\
\text { Facilities }\end{array}$ & 0 & 82 & 501 & 0 & 0 & 583 & 2.8 & -0.39 \\
\hline $\begin{array}{l}\text { Nursery/Primary } \\
\text { school }\end{array}$ & 0 & 150 & 399 & 0 & 0 & 549 & 2.64 & -0.55 \\
\hline $\begin{array}{l}\text { Transport } \\
\text { network }\end{array}$ & 0 & 156 & 333 & 16 & 20 & 525 & 2.52 & -0.67 \\
\hline Mosque & 0 & 254 & 219 & 32 & 0 & 505 & 2.43 & -0.74 \\
\hline Water supply & 2 & 338 & 84 & 36 & 0 & 460 & 2.21 & -0.98 \\
\hline
\end{tabular}

$$
\text { RSII }_{\text {Sub-urban }}=\frac{\sum R S I I}{(N=16)}=\frac{51.10}{16}=3.19 \quad \text { Source: Field Survey, } 2018
$$

The highest level of satisfaction was derived from facilities such as church, drainage, dispensary, electricity and fire station. Others included public toilet, open space and secondary school. All these had positive deviation about the mean and mean values above the average index (RSII Sub-urban $_{\text {). }}$.

\section{Conclusion and recommendations}

The study has examined infrastructural facilities in Ibadan metropolis. The study revealed that facilities such as water supply, restaurant, dispensary, drainage, electricity supply, waste disposal, and fire station, among others, were insufficiently available in the study area. This finding could hamper the residents' well-being. Thus, the study concluded that infrastructure facilities in Ibadan metropolis were poor.

Based on the findings of this study, it is significant to provide basic and adequate infrastructural facilities at all levels in sequence to enhance the standard of living of those residing in the study 
Ghana Journal of Geography Vol. 13 (1), 2021 pages 81-102

area thereby promoting the growth and development of Nigeria's public housing plans. However, the provision of basic and sufficient infrastructural facilities at all tiers of government and individual participation in infrastructure development should be regarded a criterion in assessing housing provision in Nigeria.

\section{References}

Afon, A.O. (2000). 'Use of Residents' Environmental Quality Indicator (EQI) Data in Core Residential Housing Improvement, Effective Housing in $21^{\text {st }}$ Century Nigeria, Federal University of Technology Akure.

Afon, A.O. (2007). An analysis of solid waste generation in a traditional African city: the example of Ogbomoso, Nigeria. Environment and urbanization. 19 (2): 527-53

Ajanlekoko, J. S. (2001). Sustainable Housing Development in Nigeria - The Financial and Infrastructural Implication. International Conference on Spatial Information for Sustainable Development Nairobi, Kenya.

Ajao, O.A., Oyegade, E.A. \& Gbadamosi, J.O. (2002). Ogbomoso Community: The Dawn of a New Era. Ogbomoso Community, Ogbomoso, Nigeria

Ajibola, M.O., Awodiran, O.O. \& Salu-Kosoko, O. (2013). Effects of Infrastructure on

Property Values in Unity Estate, Lagos, Nigeria International Journal of Economy, Management and Social Sciences, 2(5) May 2013, Pages: 195-201, ISSN 2306-7276, www.waprogramming.com

Alabi, M. O. (2010). Prioritizing Factors of Failure in Controlling Physical Development in Nigerian Cities, Journal of Sustainable Development in Africa, 12 (2), Clarion University of Pennsylvania, Clarion, Pennsylvania ISSN: 1520-5509

Asikhia, M.O. \& Uyoyoghene, O.T. (2011). Urban infrastructure and quality of life: A case study of Warri Metropolis, The Nigerian Journal of Research and Production 19(2), November, 2011

Bovaird, T. \& Loffler, E. (2003). Evaluating the Quality of Public Governance: Indicators, Models and Methodologies. DOI: 10.1177/0020852303693002 International Review of Administrative Sciences 2003 69: 313 http://ras.sagepub.eom/contcnt/69/3/313

Costanza, R. (2008). Quality of Life; An approach Integrating Opportunities, Human needs and Subjective Well-being. Ecological Economics 61, 267-276

Das, D. (2008). Urban Quality of Life: A case study of Guwahati. Social Indicator research, $88(2), 297-310$. 
Eastman, J.R. \& Hong, J. (2000). Multi-criteria and Multi-Objective decision making for land allocation using GIS. Massachusetts. The Clark Laboratory for Cartographic Technology and Geographic Analysis: 227-251.

Flora, C.B. (2004). Quality of Life versus Standard of Living. Rural Development News; http://www.ag.edu./centers/rdev/newsletter/winter.

Gatauwa, J.M. \& Murungi, M. (2015). Infrastructure Development and Real Estate Values in Meru County, Kenya, Research Journal of Finance and Accounting, ISSN 2222-1697 (Paper) ISSN 2222-2847, .6 (8)

Kolawole, M. (2014). An assessment of housing infrastructural Provision in Public Housing: a case study of Bashorun housing estate Akobo, Ibadan, Oyo State.

Lucas, R.E., Clark, A., Georgellis, Y. \& Diener, E. (2003). Reexamining Adaptation and the Set Point Model of Happiness: Reactions to Changes in Marital Status. Journal of Personality and Social Psychology. Issue: 84(3), 527-539.

Mabogunje, A.L. (1968). Urbanization in Nigeria. London, University Press.

Noll, H.H. (2004). Heinz-Herbert Noll Social indicators and Quality of Life Research: Background, Achievements and Current Trends, Genov, N. (Hg.) Advances in sociological knowledge, Wiesbaden, p. 151-181.

Olujimi, J.A.B. \& Bello, M.O. (2009). Effects of Infrastructural Facilities on the Rental Values of Residential Property, Journal of Social Sciences 5(4): 332-341, 2009, ISSN 15493652

Oluseyi F. (2006). Analysis of Traditional Urban Land Use Change from Remote Sensing Data: A Case Study of Ibadan City. Map Africa”. http://www.gisdevelopment.cet/proceedings/mapafrica/2006/Technology.

Omar, D. B. (2009). Assessing Residents" Quality of Life in Malaysian New Towns. Asian Social Sciences, 5(6), 94; http://www.ccsenet.org/journal/index.php/ass/article/2482/2329 Omole, F.K. (2001). Basic Issues in Housing Development. FemBless, Ondo, Nigeria.

Orekan, A.A. (2015). The Impact of Infrastructural Facilities on Residential Property Development in Ota, Ogun State Nigeria, Covenant Journal of Research in the Built Environment (CJRBE) .3 (2)

Oyesiku, O.O. (2009). City Livability: implications and Challenges, A keynote address in City Planning for Livable Human Settlements. Proceedings of 2009 Nigerian Institute of Town Planning, Commonwealth Association of Planners, West Africa Workshop, Lagos, Nigeria. Oyesiku, O.O. (2010). New Cities in Urban and Regional Development Planning. Lagos, Nigeria: Academy Press Plc.

Oyo State Independence Electoral Commission (2012). Local Government Areas in Ibadan Metropolis: Stratification into the existing political wards in Ibadan, Oyo State, Nigeria

Pacione, M. (2003). Introduction on urban environmental quality and human well-being. Landsc. Urban Plan. 65 (1/2):1-3.

Sirgy, M.J. \& Cornwell, T. (2002): How Neighborhood Features Affect Quality of Life, Social Indicators Research, Vol. 59, No. 1 (Jul., 2002), pp. 79-114Published by: Springer Stable URL: http://www.istor.org/stable/27527022 4

Udoka, I. (2013). The imperatives of the provision of infrastructure and improved property values in Nigeria. Mediterranean Journal of Social Sciences. 
Ghana Journal of Geography Vol. 13 (1), 2021 pages 81-102

United Nations (2008). World Urbanization Prospects: The 2005 Revision. New York: United Nations.

United Nations Development Programme, "Human Development Report (2004). www.hdr.undp.org/reports/global/2004.

United State Environmental Protection Agency, (USEPA) (2006). Home Buyer and Seller's Guide to Radon.

United Nations Population Fund (2007). State of the World Population. Unleashing the Potential of Urban Growth. www.unfpa.org.swp/2007.

United Nations (2008). World Investment Report 2008. Transitional Corporations, and the Infrastructure Challenge. New York and Geneva: United Nations

United Nations Economic Commission for Africa (UNECA) (2013). Report on progress in achieving the Millennium Development Goals in Africa. Addis Ababa, Ethiopia: United Nations Economic Commission for Africa.

Veenhoven, R. (2002). Why social policy needs subjective indicators. Social Indicators Research, 58 (1-3), 33-46.

Veenhoven, R. (2017). Trend inequality of happiness in nations 1946-2010: How much happiness differs across citizens, World Database of Happiness, Erasmus University Rotterdam.

http://worlddatabaseofhappiness.eur.nl/hap_nat/findingreports/TrendReport_InequalityHa ppiness.pdf

Ventegogt, S., Merrick, J., \& Andersen, N. J. (2003). Quality of Life Theory 1. The IQOL Theory: An Integrative Theory of the Global Quality of Life Concept. The Scientific World Journal, 3, 1030-1040.

World Health Organisation (WHO) (2007). WHOQOL User Manual. WHO/MHN/MHP/98.4, www.who.int/mental-health/evidencewho-qol-user- manual-98

WHOQOL Group (1998). Development of the World Health Organization WHOQOL-BREF quality of life assessment. The WHOQOL Group. Psychological Medicine, 28, 551558.

World Bank (2013). Annual report 2013. www.worldbank.org 